\title{
Challenges of private forests management in Cluwak sub-district, Pati regency, Indonesia
}

\author{
Andi Kurniawan*, Jafron Wasiq Hidayat, Amirudin \\ Master Program of Environmental Science, School of Postgraduate Studies, Diponegoro University, \\ Semarang-Indonesia
}

\begin{abstract}
The management of private forests carried out by farmers, in general, is still very simple. Land tenure is usually relatively narrow and diffuse, family-based management with limited knowledge and multi cropping in one field. Nevertheless, the benefits can already be felt by farmers both economically, ecologically, and socially. Private forests can increase land cover in the form of trees and various other types of plants. The characteristics of private forests that are generally encountered on Java are also found in the Cluwak sub-district, Pati regency. This paper will review and identify various challenges in private forest management in the Cluwak sub-district, Pati regency. Thus economically, ecologically, and socially sustainable private forest management becomes a challenge that is not impossible to realize. Data analysed descriptively from field observations, various reports, and similar research findings. Several studies have found that there are factors that influence the management of private forests such as internal factors (natural resources, human resources, farmers' group institutional, social) and external factors (markets, government assistance, and culture technique).
\end{abstract}

Keywords. Private forest, challenges, Cluwak sub-district

\section{Introduction}

Forests are one of the natural resource whose roles in various aspects of life, both economic, social, and environmental aspects. The fores as the basis for national development with a diversity of flora and fauna that can provide benefits to human life. The area of natural forests has decreased significantly, both in terms of area, quality, and function [1]. Recently, timber products from state forests are not enable to meet the demand of national timber, as human growth is increasing in Indonesia. The supply of wood raw materials for the timber industry originating from natural forests has declined in the past four years. This is shown by the data in 2015 amounting to 8.3 million $\mathrm{m}^{3}$, while in 2018 it was 5.7 million $\mathrm{m}^{3}$. Meanwhile, the supply of wood raw material from plantation forests and private forests has increased from 37.3 million $\mathrm{m}^{3}$ in 2015 to 46.6 million $\mathrm{m}^{3}$ in 2018 . Private forests can contribute to fill the portion of the forestry industry. These participations

\footnotetext{
* Corresponding author: andik.rra84@gmail.com
} 
are a very significant in supporting to the timber industry in Indonesia [2]. The supply of raw materials from private forests has increased from 4.8 million $\mathrm{m}^{3}$ in 2015 and has increased to 6.2 million $\mathrm{m}^{3}$ in 2018 [3]. Even though the management is still simple, the economic, ecological and social benefits are visible and can be taken by the community. Its role is getting bigger with the growing market demand for wood raw materials in line with the growth of the wood processing industry [4]. Management of private forests, in general, is still done traditionally, as found in Finland. But from the results of research conducted on private forest owners, they also have the desire to start implementing better management. Their motivation can also change, because forest owners are expected to different forest management, and in particular are oriented towards nature and sustainability in the future. Changes in forest management will depend on how the timber market develops, assistance and incentives applied in the future [5]. However, in practice, there are many obstacles and problems encountered in the field which have caused the management of the private forest to not run properly. Many factors can destroy private forest, one of which is the aspect of forest management that has not been implemented properly. Another obstacle that was encountered was regarding social factors. The problem of poverty became a serious challenge for sustainable management of private forests [6]. In addition to social factors in the form of poverty issues, other problems relating to private forests are low levels of land ownership, low education, and lack of skills in the non-agricultural and forestry sectors [7][8]. The purpose of this study was to determine the challenges of private forests management in the Cluwak sub-district, Pati regency. In general, private forests management in Cluwak sub-district is carried out with a monoculture system $(29 \%)$, polyculture $(61 \%)$, and agroforestry $(10 \%)$ with land use for undergrowth by $56 \%$ [9]. The hope is that the potential of existing private forests can be managed and developed properly. Private forests can be managed in a sustainable, and generate economic, environmental, and social benefits for the community.

\section{Terminology of private forest}

Private forests have been developing and cultivated for a long time, especially in Java. Terminology of private forests, in general, are forests that grow on land that is encumbered with ownership rights or other rights outside the forest area with a minimum area of 0.25 ha, canopy cover for timber, and other plants of more than $50 \%$ [10]. In contrast to state forests, where state forests are forests that grow on land that is not encumbered with state property or land rights. The difference between private forest and state forest is seen based on the status of land ownership or the nature of the object (land and forest), not based on the actors or subjects who manage the forest. Private forests are often associated with management systems and integrated land-use strategies for timber and non-timber crops, usually with dynamic and sometimes diverse goals and orientations. Based on the type of plant, a private forest can be divided into three forms of cropping patterns, namely (1) pure private forest (monoculture), which is a private forest consisting of only one species of woody plant which is planted monoculture or homogeneously, (2) mixed private forest ( polyculture), is a private forest consisting of various of woody plants which are mixed in one location, (3) agroforestry private forest, is a combination of planting that combines woody plants (forestry) with other farming commodities such as crops, plantations, integrated farms [11]. 


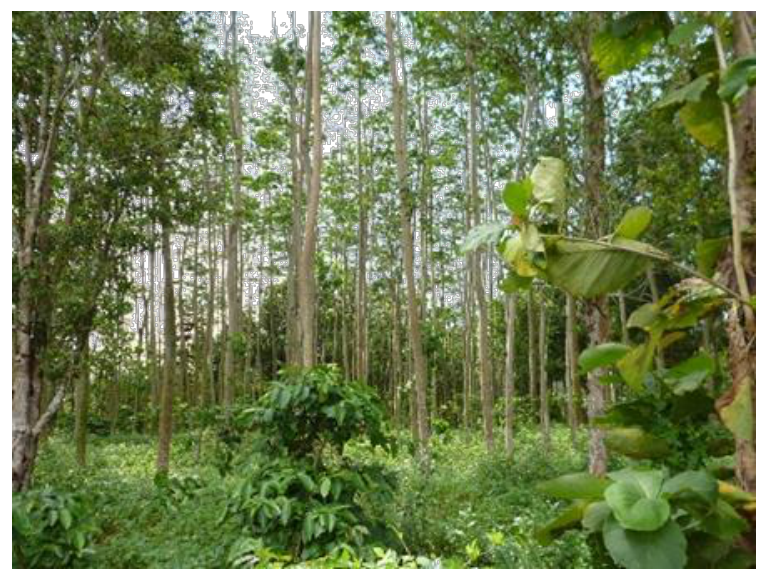

Fig. 1. Private forest of polyculture system in Cluwak sub-district

Private forest management in Pati District has many obstacles, including limited technical knowledge controlled by farmers, rust attacks on sengon species (Paraserianthes falcataria), illegal pruning, tree felling without planning, and timber sold using a standing tree estimation system (tebasan). Opportunities in the private forestry business include support from government programs, fertile land, high demand for sengon wood, and opportunities for the development of wood processing industries in their regions. The Sengon wood trade in the Pati area has just developed. The results of community wood products, especially Sengon (Paraserianthes falcataria), are sold to industries in other districts such as Semarang, Temanggung, Kebumen, and even to East Java in the form of logs of a certain size. Opportunities to develop the sengon wood processing industry in the Pati regency are very wide open so that the location of the factory is closer to the location of the supplier of raw materials so that farmers' access to the market for their products is wide open [12]. Zainal et al in his research stated that the inhibiting factors in the management of private forests in Sinjai Regency were; (a) conversion of forest land as settlements, plantations, and agriculture, (b) forestry business have not produced maximum results that threaten the sustainability of results, (c) investment in forestry is still minimal, and there is a distortion in the market of private forest products, especially wood products. While the supporting factors include; (a) forestry cultivation techniques are very easy and (b) there is government assistance in the form of seedlings procurement [13]. The same thing also happened to private forests in Pati regency, especially in Cluwak sub-district.

\section{Methodology}

This study was conducted in private forests in Cluwak sub-district, Pati regency. Data were analyzed descriptively from field observations, various reports, and similar research findings. This paper will discuss and identify various problems and challenges in private forest management in Cluwak sub-district, Pati regency. 


\section{Discussion}

\subsection{Private forests in the Cluwak sub-district, Pati regency}

Based on its morphology, most of the area of Pati Regency is lowland with an elevation ranging from $0-100 \mathrm{~m}$ above sea level. Hence the area potential enough to become an agricultural area. The morphological conditions of Pati Regency can be grouped into 3 units, namely: (1) Slopes of Mount Muria, which stretches to the west of the northern part of the Java Sea and covering the area of Gembong, Tlogowungu, Gunungwungkal, and Cluwak, (2) Lowlands stretching from the center to the north of the Java Sea, covering part of it Dukuhseti, Tayu, Margoyoso, Wedarijaksa, Juwana, Winong, Gabus, Kayen subdistricts the northern part, the northern part of Sukolilo, and the northern part of Tambakromo, (3) Karst Mountains (Kendeng mountains), which stretch to the south covering a small area Sukolilo, Kayen, Tambakromo, Winong, and Pucakwangi [14]. The vastly developed private forest in the South Pati region (Kendeng mountains) is dominated by Teak (Tectona grandis) species. An inventory of private forests carried out by the forestry and plantation services of the Pati Regency in 2015 showed that Teak (Tectona grandis) had the highest index of importance value (258.69\%) [9]. Although now it has also begun to be encountered by many people who plant the Sengon (Paraserianthes falcataria) species. The community began to be interested in planting Sengon due to the relatively short cycle of production, by the age 5-6 years its can be harvested. Whereas for Teak plants require a cycle that is long enough for decades. The private forests that develop on the Muria mountains are more complex and varied compared to those that develop in southern Pati hillaries. The soil types in the Muria mountains are dominated by latosol [14], whilst the characteristics include (1) having sufficiently thick soil solum, (2) red, brown to yellowish soil, (3) soil texture in general clay, (4) crumb soil structure loose consistency, and (5) contains moderate to high nutrients. By nature, the soil on the slopes of the Muria mountains is more fertile, making it suitable for crop cultivation and allows for many types of plants to be planted. Perennial plants that are widely cultivated by the community is Sengon (Paraserianthes falcataria). The patterns of private forest management are even more varied, such as monoculture, polyculture, and agroforestry.

Cluwak sub-district consists of 13 villages with a potential private forest area of 3,700 ha, with the potential for tree crops dominated by Sengon (Paraserianthes falcataria), while for estate crops farmers cultivate types of Coffee and Clove. As for the type of coffee that is mostly cultivated is Robusta coffee, there are 3 coffee-producing villages namely Medani, Sentul, and Payak. Clove plants can be found in almost every village. Clove cultivation is widely practiced by the community because economically, the selling price is relatively high. The distribution of private forests in Cluwak sub-district can be seen in Fig. 2 below. 


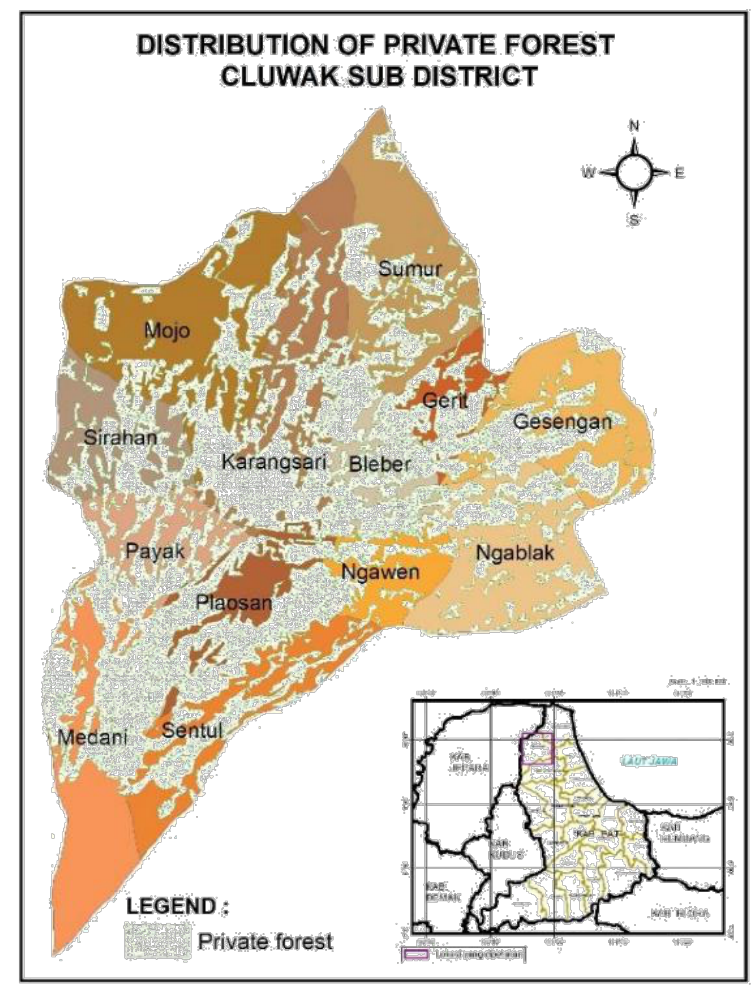

Fig. 2. Distribution of private forests in Cluwak sub-district

In general, private forest management in Cluwak sub-district is carried out with a monoculture system $(29 \%)$, polyculture $(61 \%)$, and agroforestry $(10 \%)$ with land use for undergrowth by $56 \%$. The inventory results show that four types have the greatest potential which is marked with the highest Importance Value Index (INP), namely Sengon, Mahogany, Teak, and Weru. Sengon (Paraserianthes falcataria) occupy the highest rank because this species is a type of short cycle with high economic value so that the enthusiasm of the community to Sengon (Paraserianthes falcataria) is very high. Tree level rejuvenation is dominated by Sengon species. To increase the potential value and benefit value of private forests in the Cluwak sub-district, four types of local trees have high economic value that can be developed, namely Sengon, Teak, Mahogany, and Weru [9]. Mixed private forest (polyculture and agroforestry) is considered to fulfill the principles of sustainability and business feasibility more than a private forest with a pure pattern (monoculture). The mixed rights forest produces quite high timber production and other products so that it can increase the income of the owner farmers. In mixed community forests, pests and diseases that attack plants are rarely found, even when the Sengon (Paraserianthes falcataria) species are more than eight years old. The absence of pests and diseases in mixed rights forest areas shows that from an environmental/ecological aspect, mixed rights forests are better than pure forests because they have high resistance to pests and diseases [15]. 
Table 1. Potential area of private forests in Cluwak sub-distrct

\begin{tabular}{|c|c|c|c|}
\hline No & Village & $\begin{array}{c}\text { Total area of private } \\
\text { forest }(\mathrm{Ha})\end{array}$ & Dominant species \\
\hline 1 & Bleber & 258,657 & $\begin{array}{c}\text { Sengon }(77,9 \%) \text {, Mahoni }(15,6 \%) \text {, } \\
\text { other species }(6,5 \%)\end{array}$ \\
\hline 2 & Gerit & 244,445 & $\begin{array}{c}\text { Mahoni }(58,7 \%) \text {, Sengon }(20,9 \%) \text {, } \\
\text { other species }(20,4 \%)\end{array}$ \\
\hline 3 & Gesengan & 247,349 & $\begin{array}{c}\text { Mahoni }(71,1 \%) \text {, Sengon }(22,8 \%) \text {, } \\
\text { other species }(6,1 \%)\end{array}$ \\
\hline 4 & Karangsari & 530,240 & $\begin{array}{c}\text { Sengon }(54,8 \%) \text {, Mahoni }(34,8 \%) \text {, } \\
\text { other species }(10,4 \%)\end{array}$ \\
\hline 5 & Medani & 354,124 & $\begin{array}{c}\text { Sengon }(72,6 \%) \text {, Mahoni }(14,2 \%) \text {, } \\
\text { other species }(13,2 \%)\end{array}$ \\
\hline 6 & Mojo & 431,572 & $\begin{array}{c}\text { Sengon }(66,4 \%) \text {, Mahoni }(15,5 \%) \text {, } \\
\text { other species }(18,1 \%)\end{array}$ \\
\hline 7 & Ngablak & 221,946 & $\begin{array}{c}\text { Sengon }(53 \%) \text {, Mahoni }(33,7 \%) \text {, } \\
\text { other species }(13,3 \%)\end{array}$ \\
\hline 8 & Ngawen & 161,292 & $\begin{array}{c}\text { Sengon }(63 \%) \text {, Mahoni }(21,7 \%) \text {, } \\
\text { other species }(15,3 \%)\end{array}$ \\
\hline 9 & Payak & 192,763 & $\begin{array}{c}\text { Sengon }(87,3 \%) \text {, Mahoni }(10,1 \%) \text {, } \\
\text { other species }(2,6 \%)\end{array}$ \\
\hline 10 & Plaosan & 314,548 & $\begin{array}{c}\text { Sengon }(58,2 \%) \text {, Mahoni }(15,9 \%) \text {, } \\
\text { other species }(25,9 \%)\end{array}$ \\
\hline 11 & Sentul & 356,980 & $\begin{array}{c}\text { Sengon }(74,5 \%) \text {, Mahoni }(16,5 \%) \text {, } \\
\text { other species }(9 \%)\end{array}$ \\
\hline 12 & Sirahan & 138,338 & $\begin{array}{c}\text { Sengon }(85,4 \%) \text {, Mahoni }(10,9 \%) \\
\text { other species }(3,7 \%)\end{array}$ \\
\hline 13 & Sumur & 248,067 & $\begin{array}{c}\text { Sengon ( } 46,9 \%) \text {, Jati }(36,7 \%) \text {, other } \\
\text { species }(16,4 \%)\end{array}$ \\
\hline
\end{tabular}

Source: The forestry and plantation services of pati regency (2015)

\subsection{Challenge of private forests management in Cluwak sub-district, Pati regency}

There are several challenges encountered in private forest management in the Cluwak subdistrict, Pati regency. Factors affecting the management of private forests come from internal and external factors, as follows.

\subsubsection{Ownership and management of private forests}

Private forests in Java have characteristics that are a challenge in their management [16], as well as those found in private forests in Cluwak sub-district Pati regency including:

1. A relatively narrow and spread out area

Ownership of private forests in Java is generally under 1 ha, some even less than 0.25 ha. Many private forests are built on degraded land with steep slopes and top of hills, flat areas tend to be used for agriculture commodities. Trees are generally planted as protection or in the remaining spaces of other commodities such as land boundaries, paddy fields, and marginal lands [17]. 
2. Planting patterns vary

The community will plant with many types of plants in one location so that it will create problems when an inventory, determination of potential and yield regulation will be carried out to meet the principles of sustainable forest management.

3. Family-based management (without management system)

Generally, private forest management is carried out from generation to generation and has become a custom or tradition of the local community. Farmers have never recorded or documented activities, and generally apply a need-based cutting system.

4. Limited technical knowledge of farmers

Technical knowledge about private forest management is still lacking, both about proper cultivation methods, regulations, and marketing of the produce. Community timber is usually sold to intermediary timber traders using a standing tree estimation system (tebasan). So that the price of wood will be the same, this of course can harm farmers. Wood has a quality measure which of course affects the selling price. In addition to the circulation of timber originating from private forests, some limits are regulated by the Ministry of Forestry and the Environment.

\subsubsection{Social poverty}

The average owner or farm labor of private forests has a limited economic capacity, while the necessities of life must still be met and even tend to increase. Assistance from the government is needed to overcome the problem of poverty. This assistance can be in the form of policies that are more pro-community to the owners or tenants of private forests, direct and continuous assistance as well as more tangible assistance such as plant seeds and fertilizers. So that the right strategy is needed in the management of private forests, to obtain results that can be put to good use and sustainable private forests.

\subsubsection{Timber legality certification}

Foreign markets require that both wood and products derived from processed wood must come from legal wood. Have a timber legality verification certificate that is recognized internationally. Wood products and raw materials are obtained or come from sources whose origins and management meet aspects of legality. Timber can be called legal if the origin of the wood, the logging permit, the systems and procedures for felling, transporting, processing, and trading or transferring it can be proven that it fulfills all applicable legal requirements. Governments in several importing countries impose regulations to prove the legality of circulating wood products, including those originating from imports, in each country. Like the United States Government (US) imposed the Lacey Act, the European Union (EU) with the Timber Regulation, Australia with the Illegal Logging Prohibition Act, and Japan with the Green Konyuho (GoHo Wood) [18]. For private forests with all its limitations, this is a challenge in itself to create sustainable management so that the products produced can be accepted in the international market. The problem encountered in the field is the absence of a solid private forest management (institutional) organization. Management that is still individual can be pushed into management that is group, so that management will be easier to manage. This management includes such as area management, forest management units, logging or harvesting of private forests, marketing or post-production, environmental and social management, and forest exploitation plans [16]. Besides, it also concerns the costs required in the certification process. Small industries and private forests will be ready to implement timber legality certification if there is a guarantee of higher prices and additional market access. But if there is no guarantee of 
an increase in price, then they will be reluctant to take care of the timber legality certification because the costs are quite large [19].

\subsubsection{Build partnerships}

The management of private forests needs to be maintained to increase benefits, especially to the community as the owner. One of the determining factors in the success of private forest management is the role and linkages between private forest actors. The perpetrators are private forest farmers, farmer groups, middlemen, industry, and local government partners. These actors, also known as the three pillars of development, can be grouped into three groups: civil society, entrepreneurs (private sector), and government (state). Most of the private forests in Java are on private property. In this case, the government can act as a facilitator, planner, implementer, and monitor and evaluator of programs that support private forest development. The private sector acts as a market that accommodates products from private forests. While the community as landowners have an important role, as managers of private forests. Positioning private forest stakeholders in a bond such as partnership can build and develop interactive communication and information sharing among private forest actors. Although decisions related to forest management remain in the hands of the community as the owner, the role of other stakeholders in sharing information and other forms of service will influence the community in making decisions [20].

\subsubsection{Institutional strengthening}

The institutionalization of farmer groups in each village in the Cluwak sub-district has been formed for quite a long time. In the current condition, several groups are not active in their activities. While those who are active in carrying out activities, routinely carry out group meetings which are usually held once a month with assistance from forestry and agriculture extension agents. Farmer groups need to be pushed back to be more active in activities, the government can provide incentives that encourage farmer groups to advance. Some weaknesses found in farmer group institutions include, (1) incomplete group administration books, (2) absence of routine meetings, (3) groups will be active if there are activities, such as when receiving assistance from the government, (4) group administrators who are less competent, (5) less independent and too dependent on the government.

\section{Conclusion}

The potential for private forests is quite large in Cluwak Subdistrict, Pati Regency (3,700 ha), raising hopes that this community forest can contribute to improving community welfare. This is supported by soil morphological conditions in the cluwak sub-district, with the dominance of latosol soil types which are quite fertile and also very supportive for the cultivation of various types of plants. This can be realized if private forests can be managed properly, not only providing economic benefits, but also ecological and social benefits. Support and cooperation from various stakeholders are needed. Factors affecting the management of private forests include internal factors (natural resources, human resources, farmers' group institutional, social) and external factors (markets, government assistance, and culture technique). 


\section{References}

[1] KLHK, "Siaran Pers - Hutan dan Deforestasi Indonesia Tahun 2019," 2020. [Online]. Available: http://ppid.menlhk.go.id/. [Accessed: 01-Aug-2020].

[2] "Hutan Rakyat Jawa Pasok 40\% Kebutuhan Kayu." [Online]. Available: https://www.antaranews.com/berita/207780/hutan-rakyat-jawa-pasok-40-kebutuhankayu. [Accessed: 28-Jul-2020].

[3] KLHK, "Siaran Pers - Bangkitnya Industri Kayu Nasional Dari Jawa Tengah Untuk Indonesia.," 2019. [Online]. Available: http://ppid.menlhk.go.id/. [Accessed: 12-Jun2020].

[4] T. Puspitojati, M. . Mile, E. Fauziah, and D. Darusman, Hutan Rakyat: Sumbangsih Masyarakat Pedesaan untuk Hutan Tanaman. Yogyakarta: Penerbit Kanisius (2014)

[5] A. Juutinen, A. Tolvanen, and T. Koskela, "Forest owners' future intentions for forest management," For. Policy Econ., 118, March, p. 102220 (2020)

[6] T. Sukwika, D. Darusman, C. Kusmana, and D. R. Nurrochmat, "Skenario Kebijakan Pengelolaan Hutan Rakyat Berkelanjutan Di Kabupaten Bogor," J. Pengelolaan Sumberd. Alam dan Lingkung, 8, 2, 207-215 (2018)

[7] C. Kusmana, "Forest resources and forestry in Indonesia," Forest Sci. Technol., 7, 4, $155-160(2011)$

[8] S. Kant et al., "New frontiers of forest economics," For. Policy Econ., 35, 1-8, (2013)

[9] Dishutbun, "Inventarisasi Hutan Rakyat," Kabupaten Pati (2015)

[10] Menhut, Permenhut No: P.9/Menhut-II tentang Tata Cara Pelaksanaan, Kegiatan Pendukung dan Pemberian Insentif Kegiatan Rehabilitasi Hutan dan Lahan (2013)

[11] Hardjanto, "Keragaman dan Pengembangan Usaha Kayu Rakyat di Pulau Jawa (Disertasi)," Bogor: Institut Pertanian Bogor (2003)

[12] S. Irawati, A. . Suka, and S. Ekawati, "Manfaat Ekonomi dan Peluang Pengembangan Hutan Rakyat Sengon di Kabupaten Pati," J. Penelit. Sos. dan Ekon. Kehutan., 9, 3, 126-139 (2012)

[13] L. . Zainal, A. Tjoneng, and S. Numba, "Strategi Pengelolaan Hutan Rakyat di Kabupaten Sinjai," J. Agrotek, 3, 1, 10-23 (2019)

[14] Direktorat Jendral Cipta Karya Kementrian Pekerjaan Umum, "Profil Kabupaten Pati," Penyusunan Rencana Terpadu dan Progr. Investasi Infrastruktur Jangka Menengah Kabupaten Pati Tahun 2015-2019, pp. 1-037 (2015)

[15] A. Widiarti and S. Prajadinata, "Karakteristik Hutan Rakyat Pola Kebun Campuran,"J. Penelit. Hutan dan Konserv. Alam, V, 2, 145-156 (2008)

[16] E. Suprapto and D. Nugroho, "Strategi Pendampingan Hutan Rakyat: Pengalaman Sertifikasi Pengelolaan Hutan Rakyat. (ed) Hutan Rakyat Di Simpang Jalan," Yogyakarta: Gadjah Mada University Press, pp. 255-280 (2017)

[17] D. Darusman and Hardjanto, "Tinjauan Ekonomi Hutan Rakyat," Semin. Has. Penelit. Has. Hutan, pp. 4-13 (2006)

[18] "Tentang [Online]. SVLK." Available: http://silk.dephut.go.id/index.php/info/vsvlk/1. [Accessed: 30-May-2020].

[19] E. Yosefi Suryandari, D. Djaenudin, and I. Alviya, "Persepsi Pelaku Hutan Rakyat Dan Industri Kayu Skala Kecil-Menengah Terhadap Kesiapan Implementasi Svlk,"J. Anal. Kebijak. Kehutan., 4, 2, 149-164 (2017)

[20] A. Bisjoe, "Inisiasi dan Implementasi Kemitraan Pengelolaan Hutan Rakyat. (ed) Kemitraan Pengelolaan Hutan Rakyat: Pemberlajaran dari Bukukumba, Sulawesi Selatan," Bogor: Forda Press, pp. 13-27 (2016) 